\title{
PEMANFAATAN VIDEO TUTORIAL DENGAN CAMTASIA \\ UNTUK MENINGKATKAN MINAT DAN HASIL BELAJAR SISWA DALAM \\ PEMBELAJARAN MENGGAMBAR DENGAN PERANGKAT LUNAK \\ PADA SISWA KELAS X TGB B DI SMK NEGERI 4 SUKOHARJO \\ TAHUN AJARAN 2016/2017
}

\author{
Ibnu Candra Hakim', Sukatiman², Budi Siswanto ${ }^{3}$ \\ Universitas Sebelas Maret \\ Email: ibnucandra@student.uns.ac.id
}

\begin{abstract}
Abstrak: Tujuan penelitian ini adalah untuk (1) meningkatkan minat belajar siswa kelas X TGB B di SMK Negeri 4 Sukoharjo tahun pelajaran 2016/2017 pada mata pelajaran Menggambar dengan Perangkat Lunak, (2) meningkatkan hasil belajar siswa kelas X TGB B di SMK Negeri 4 Sukoharjo tahun pelajaran 2016/2017 pada mata pelajaran menggambar dengan perangkat lunak menggunakan media video Tutorial dengan Camtasia. Penelitian ini merupakan penelitian tindakan kelas yang terdiri dari dua siklus, setiap siklus terdiri dari perencanaan, pelaksanaan tindakan, dan refleksi. Subyek penelitian adalah siswa kelas X TGB B SMK Negeri 4 Sukoharjo tahun pelajaran 2016/2017. Sumber data berasal dari wali kelas, kepala tata usaha dan siswa kelas X TGB B SMK Negeri 4 Sukoharjo yang diperoleh melalui observasi, dokumentasi, dan tes. Teknik analisis data yang digunakan adalah analisis deskriptif komparatif. Hasil penelitian menunjukkan bahwa media video tutorial dengan Camtasia dapat meningkatkan minat belajar siswa pada siklus I sebesar $72,14 \%$ dengan persentase ketercapaian $75 \%$ menjadi $78,81 \%$ pada siklus II. Hasil belajar siswa juga meningkat dari prasiklus sebesar $45,71 \%$ menjadi $71,43 \%$ pada siklus I dan 80,00\% pada siklus II. Simpulan penelitian ini adalah penerapan media video tutorial dengan Camtasia dapat meningkatkan minat belajar dan hasil belajar siswa pada mata pelajaran menggambar dengan perangkat lunak siswa kelas X TGB B SMK Negeri 4 Sukoharjo Tahun Pelajaran 2016/2017.
\end{abstract}

Kata Kunci: Penelitian Tindakan Kelas, Media Video Tutorial dengan Camtasia, Minat Belajar, Hasil Belajar.

\footnotetext{
${ }^{1}$ Mahasiswa Pendidikan TeknikBangunan FKIP UNS

${ }^{2}$ Dosen Pembimbing I

${ }^{3}$ Dosen Pembimbing II
} 
THE USE OF TUTORIAL VIDEOS WITH CAMTASIA

TO INCREASE INTEREST AND STUDENT LEARNING RESULTS

IN DRAWING WITH SOFTWARE IN STUDENT CLASS X TGB B

IN SMK NEGERI 4 SUKOHARJO ACADEMIC YEAR 2016/2017

\author{
Ibnu Candra Hakim¹, Sukatiman², Budi Siswanto ${ }^{3}$ \\ Sebelas Maret University \\ Email: ibnucandra@ student.uns.ac.id
}

\begin{abstract}
The purposes of this study was (1) increase the interest of learning class X TGB B SMK Negeri 4 Sukoharjo at academic year 2016/2017 on the subject of drawing with software and, (2) increase the student learning outcomes of class X TGB B SMK Negeri 4 Sukoharjo at academic year 2016/2017 on the subjects of Drawing with software by using Tutorial video media with Camtasia. This classroom action research consisted of two cycles. Each cycle consisted of planning, running action, observation, and reflection. The research subject were teacher and students of class X TGB B SMK Negeri 4 Sukoharjo at academic year 2016/2017. The source of data comes from the vice class teacher, the head of the administration and students of class X TGB B SMK Negeri 4 Sukoharjo obtained through observation, documentation, and test. The data analysis technique used was comparative descriptive analysis. The results of the research showed that the Tutorial video media with Camtasia can improved student interest from the first cycle of 72,14\% to 78,81\% in the second cycle. Student learning outcomes of preassue also increased by $45.71 \%$ to $71.43 \%$ in the first cycle and $80.00 \%$ in the second cycle. The conclusion of this research was the application of Tutorial video media with Camtasia can increased learning interest and student learning outcomes in subject drawing with software class $X$ SMK TGB B 4 Sukoharjo at academic year 2016/2017.
\end{abstract}

Keyword: Classroom Action Research, Tutorial Video with Camtasia, Interest, Learning Outcome

\footnotetext{
${ }^{1}$ Mahasiswa Pendidikan TeknikBangunan FKIP UNS

2 Dosen Pembimbing I

${ }^{3}$ Dosen Pembimbing II
} 


\section{PENDAHULUAN}

Sekolah

Menengah

Kejuruan (SMK) merupakan salah satu institusi dalam dunia pendidikan yang mampu menyiapkan lulusannya untuk dapat diserap dunia kerja. Lulusan SMK diharapkan memiliki kompetensi keahlian dalam bidangnya, terampil dan berdaya saing tinggi. Alasan tersebut menjadi acuan bahwa pendidikan di SMK harus berkualitas dan meningkat seiring perkembangan serta tuntutan dunia kerja.

SMK Negeri 4 Sukoharjo merupakan unit sekolah yang baru berusia 9 tahun. Sekolah ini memiliki 4 bidang keahlian yaitu Teknik Gambar Bangunan (TGB), Teknik Perbaikan Bodi Otomotif (TPBO), Teknik Busana Butik (TBB), dan Teknik Permesinan (TP). TGB memiliki 7 kelas yang terdiri dari kelas $\mathrm{X}$ sebanyak 3 kelas, kelas XI sebanyak 2, dan kelas XII sebanyak 2 kelas. TGB memiliki jadwal mata pelajaran normatif dan kompetensi produktif yang sangat padat dalam setiap minggunya. Kompetensi Produktif di TGB diampu oleh 5 orang guru yang juga merangkap sebagai pengurus dalam institusi SMK Negeri 4 Sukoharjo. Metode pembelajaran yang digunakan adalah metode instruksi langsung siswa tidak dimonitor saat kegiatan pembelajaran berlangsung. Kondisi ini membuat proses belajar mengajar kurang efektif. Idealnya siswa mencatat materi menggambar dengan perangkat lunak yang sedang berlangsung tapi kondisi dilapangan berbeda, pada saat pembelajaran menggambar dengan perangkat lunak di kelas X TGB B siswa tidak dapat mencatat materi karena tidak adanya kesempatan mencatat. Hal ini mengurangi minat siswa dalam mengikuti pembelajaran sehingga pemahaman dan keterampilan setiap siswa masih rendah. Pembelajaran yang berpusat kepada guru, tidak memberikan kesempatan kepada siswa sehingga aktivitas bertanya tidak berjalan. Sehingga dari awal sampai akhir pembelajaran tidak melibatkan kemandirian siswa untuk menyelesaikan permasalahannya. Hal ini menyebabkan hasil belajar 
siswa rendah. Nilai terendah yang diperoleh siswa yaitu 55 sebanyak 3 orang sedangkan nilai tertinggi yaitu 82 sebanyak 1 orang dengan ketuntasan nilai minimum 75. Minat dan hasil belajar siswa perlu ditingkatkan untuk memenuhi tuntutan dunia kerja. Suheri dalam Rengga (2014: 2) menyebutkan bahwa, "Lembaga Riset dan Penerbitan Komputer, yaitu Computer Technology Research (CTR) menemukan bahwa orang hanya mampu mengingat $20 \%$ dari apa yang dilihat, dan $30 \%$ dari apa yang didengar, tetapi orang dapat mengingat $50 \%$ dari yang dilihat dan didengar, dan $80 \%$ dari yang dilihat, didengar dan dilakukan sekaligus". Dengan adanya media video tutorial pembelajaran di SMK Negeri 4 Sukoharjo, siswa dapat melihat dan mempraktekkan materi pembelajaran secara mandiri di rumah dan tidak belajar berdasarkan ingatan materi yang telah disampaikan.

Penelitian tentang minat dan hasil belajar yang belum memenuhi target ketuntasan pada siswa sudah pernah dilakukan lam laporan skripsi tentang video pembelajaran, ditemukan bahwa penerapan video pembelajaran mampu mengatasi minat dan hasil belajar siswa yang belum mencapai target ketuntasan. Berdasarkan temuan ini maka dari itu dilakukan penelitian video tutorial dengan Camtasia studio yang dikembangkan oleh TechSmith. Peneleti membuat video tutorial dengan Camtasia berisikan tahapan dalam pengerjaan yang mudah dipahami siswa. Menurut Susilana \& Riyana (2009: 147) mengemukakan bahwa "Model tutorial adalah pembelajaran melalui komputer, siswa dikondisikan untuk mengikuti alur pembelajaran yang sudah terprogram dengan penyajian materi dan latihan soal".

Pembelajaran menggunakan video tutorial dengan Camtasia ini dapat memberi kesempatan kepada siswa untuk belajar lebih fokus dan mudah untuk mengerti. Menurut Aripin (2009: 2) menyatakan bahwa "Camtasia Studio dapat membantu dan melatih kita dalam menyampaikan serta berinteraksi dengan audiens. Camtasia studio memiliki kemampuan untuk merekam suara yang ada dalam 
layar termasuk kegiatan di desktop, presentasi powerpoint, narasi suara, dan webcam Camtasia studio adalah salah satu solusi lengkap untuk menciptakan video propesional dan aktivitas desktop PC dengan cepat. Siapapun dapat merekam dan menciptakan satu pelajaran penuh video gerak atau presentasi, dengan pasti, dan terbitkan ini pada format dari pilihan mereka.” Pembelajaran $\mathrm{CAD} /$ menggambar dengan perangkat lunak dengan berbasis video tutorial perlu dilaksanakan agar minat dan hasil belajar siswa meningkat.

\section{METODE PENELITIAN}

Penelitian ini merupakan penelitian tindakan kelas. Penelitian ini menggunakan sumber data berupa pernyataan siswa dan guru yang diperoleh dari hasil wawancara yang dilakukan peneliti berkaitan dengan proses pembelajaran dan pemahaman terhadap materi, hasil observasi peneliti yang dilakukan melalui pengamatan, dokumentasi selama pembelajaran berlangsung berupa foto, dan nilai pekerjaan siswa. Teknik pengumpulan data yang digunakan sebagai berikut: wawancara yang dilaksanakan oleh peneliti terhadap guru mata pelajaran Menggambar dengan perangkat lunak dan perwakilan siswa kelas X TGB B SMK Negeri 4 Sukoharjo yang dilaksanakan peneliti secara terstruktur, observasi dilaksanakan peneliti pada mata pelajaran menggambar dengan perangkat lunak selama pembelajaran berlangsung, dokumentasi berupa data sebelum dan sesudah dilaksanakan penelitian seperti dokumentasi RPP dan Silabus, bahan ajar, presensi kehadiran siswa, foto, lembar penilaian siswa, tes dan metode pekerjaan siswa dilakukan untuk mengetahui hasil belajar ranah kognitif dan psikomotorik siswa.

Teknik uji validitas data digunakan untuk mendapatkan data yang akurat. Menurut Sutopo (2002: 80) teknik uji validitas data menggunakan teknik triangulasi data dimana data yang sejenis akan digali dari beberapa sumber data yang berbeda supaya tertuju kemantapan dan kebenarannya. Dalam penelitian ini, sumber data 
yang digunakan peneliti adalah guru mata pelajaran dan siswa. Teknik analisis data yang digunakan dalam penelitian ini sebagai berikut 1 . Analisis data hasil belajar ranah kognitif diambil dari hasil tes. Dalam penelitian ini akan diadakan tes pada akhir siklus I dan II. Analisis data dari tugas tersebut tujuannya untuk mengetahui hasil belajar pada ranah kognitif mata pelajaran Menggambar dengan Perangkat Lunak dengan menggunakan Video Tutorial dengan Camtasia. Ketuntasan hasil belajar siswa disajikan dalam persentase. Siswa dikatakan tuntas apabila nilai yang diperoleh mencapai Kriteria Ketuntasan Minimal (KKM) yang ditentukan SMK Negeri 4 Sukoharjo yaitu 75. 2. Analisis data minat dan hasil belajar ranah psikomotorik diambil dari observasi. Untuk penilaian minat belajar difokuskan pada Sikap, Kemauan, Ketertarikan, Dorongan, Ketekunan, dan Perhatian (Sri Muryanti, 2014: 12). Sedangkan untuk penilaian ranah psikomotorik (keterampilan) memfokuskan pada aspek yaitu
Persepsi, Kesiapan, Gerakan terbimbing, Gerakan terbiasa, Gerakan yang kompleks, Penyesuaian dan keaslian. Salah satu cara mengukur ranah psikomotorik adalah dengan observasi, instrumen yang digunakan adalah lembar observasi. Analisis data pada minat belajar siswa menggunakan statistik deskriptif. Data hasil observasi dianalisis dengan mendeskripsikan minat belajar siswa selama pembelajaran berlangsung. Hasil observasi minat belajar siswa dianalisis dengan mencari persentase siswa yang aktif dalam setiap indikator minat yang telah ditentukan.

Persentase tersebut dapat diketahui dengan rumus sebagai berikut:

$$
P=\frac{\text { jumlah siswa aktif }}{\text { jumlah seluruh siswa }} \times 100 \%
$$

Sumber: Sudijono, (2005: 43)

$$
\text { Indikator kerja yang }
$$
digunakan untuk ranah kognitif dan Psikomotorik adalah nilai $75 \%$ siswa memperoleh nilai 75 . Sedangkan minat belajar adalah sebanyak $75 \%$ siswa memperoleh kategori tuntas. Prosedur 
penelitiannya berupa siklus yang terdiri dari perencanaan, pelaksanaan, pengamatan, dan refleksi.

\section{HASIL TINDAKAN DAN PEMBAHASAN}

\section{Hasil Tindakan}

1. Pratindakan

$$
\text { Pelaksanaan pratindakan }
$$

penelitian ini dilakukan sebelum adanya tindakan penerapan video tutorial dengan Camtasia yang bertujuan untuk mengetahui permasalahan yang timbul pada proses pembelajaran Menggambar dengan Perangkat Lunak dilaksanakan pada hari Selasa, 11 April 2017. Terdapat 3 aspek yang dinilai yaitu minat belajar, hasil belajar ranah kognitif, dan hasil belajar ranah psikomotorik. Berikut minat belajar siswa kelas X TGB B pada pratindakan:

\begin{tabular}{lll}
\hline No & Aspek yang Diukur & Persentase \\
\hline 1 & Sikap & $63,57 \%$ \\
2 & Kemauan & $69,29 \%$ \\
3 & Ketertarikan & $75,00 \%$ \\
4 & Dorongan & $70,00 \%$ \\
5 & Ketekunan & $67,86 \%$ \\
6 & Perhatian & $64,29 \%$ \\
\hline Rata-rata Persentase & $68,33 \%$ \\
\hline
\end{tabular}

\begin{tabular}{|c|c|}
\hline Target Ketercapaian & $75 \%$ \\
\hline Kategori Ketercapaian & Tidak \\
\hline
\end{tabular}

bahwa persentase minat belajar siswa masih belum memenuhi standar 75\%, aspek tertinggi ketertarikan karena siswa merasa pembelajaran menggambar dengan perangkat lunak menarik dan aspek terendah adalah sikap karena sikap yang ditunjukan dalam pembelajaran kurang baik.

Data hasil belajar siswa ranah kognitif disajikan oleh diagram pada Gambar 1 berikut ini:

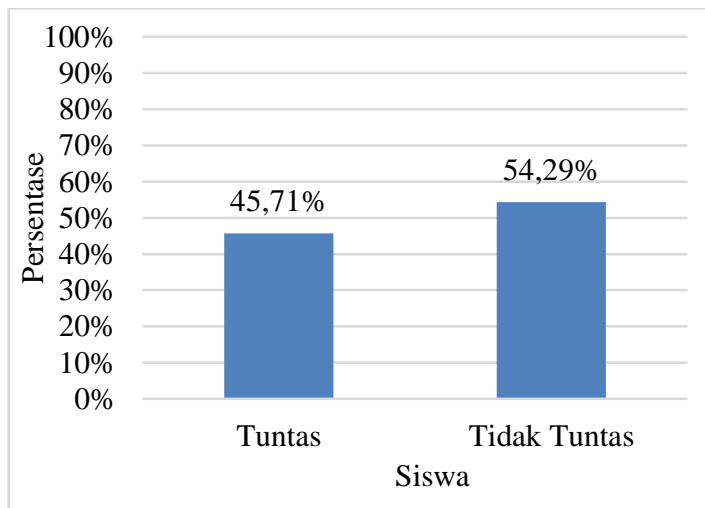

Gambar 1 Hasil Belajar Ranah Kognitif sebelum Penerapan Video Tutorial dengan Camtasia

Berdasarkan gambar 2 bahwa pada hasil belajar ranah Kognitif pratindakan, $45,71 \%$ atau 16 siswa memperoleh nilai yang 
belum memenuhi nilai ketuntasan minimal 75 , sedangkan siswa yang sudah memenuhi nilai ketuntasan minimal 54,29\% atau 19 siswa.

Data hasil belajar siswa ranah psikomotorik disajikan oleh diagram pada Gambar 2 berikut ini:

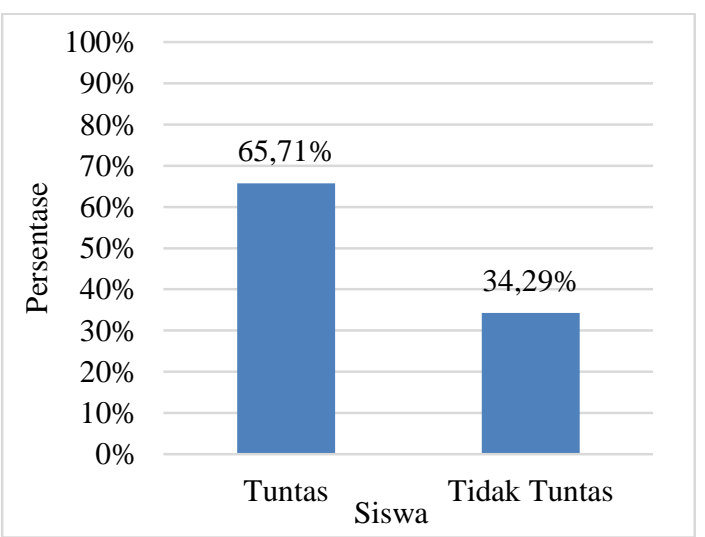

Gambar 2 Hasil Belajar Ranah Psikomotorik sebelum Penerapan Video Tutorial dengan

\section{Camtasia}

Pada hasil belajar ranah Kognitif pratindakan, 34,29\% atau 12 siswa memperoleh nilai yang belum memenuhi nilai ketuntasan minimal 75 , sedangkan siswa yang sudah memenuhi nilai ketubtasan minimal $65,71 \%$ atau 23 siswa.

2. Siklus I

Data siklus I dilaksanakan pada hari Selasa, 25 April 2017. Berikut minat belajar siswa kelas $\mathrm{X}$ TGB B pada siklus I:

\begin{tabular}{lll}
\hline No & Aspek yang Diukur & Persentase \\
\hline 1 & Sikap & $69,29 \%$ \\
2 & Kemauan & $70,00 \%$ \\
3 & Ketertarikan & $77,86 \%$ \\
4 & Dorongan & $71,43 \%$ \\
5 & Ketekunan & $73,57 \%$ \\
6 & Perhatian & $70,71 \%$
\end{tabular}

\begin{tabular}{|c|c|}
\hline Rata-rata Persentase & $72,41 \%$ \\
\hline Target Ketercapaian & $75 \%$ \\
\hline Kategori Ketercapaian & Tidak \\
\hline
\end{tabular}

bahwa persentase minat belajar siswa masih belum memenuhi standar 75\%, aspek tertinggi ketertarikan karena siswa merasa tertarik dalam belajar dengan penerapan video tutorial Camtasia dan aspek terendah adalah sikap karena dalam pembelajaran siswa merasa video tutorial terlalu cepat dan membuat mereka tertinggal dalam hal mengerjakan maka ada siswa yang membuka program lain saat pembelajaran berlangsung.

Data hasil belajar siswa ranah kognitif disajikan oleh diagram pada Gambar 3 berikut ini

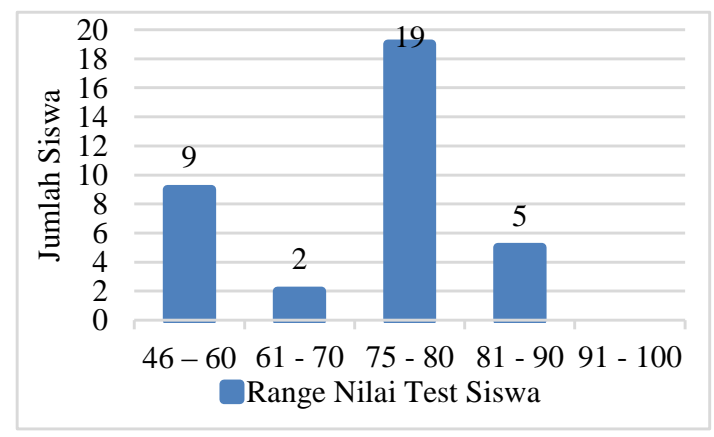


Data hasil belajar siswa

Gambar 3 Hasil Belajar Ranah Kognitif setelah Penerapan Video Tutorial dengan Camtasia Siklus I

\begin{abstract}
Berdasarkan Gambar 3 jumlah perolehan nilai ranah kognitif siklus $I \geq 75$, bertambah dibandingkan nilai ranah kognitif prasiklus. Jumlahnya menjadi 25 siswa, sedangkan jumlah siswa ranah kognitif yang memperoleh nilai $<75$ sebanyak 10 siswa.
\end{abstract}

Keberhasilan hasil belajar kognitif dalam penelitian ini dilihat dari aspek ketuntasan hasil belajar yang terdiri dari input, proses, dan output. Input berupa hasil nilai siswa dari hasil prasiklus. Proses berupa penerapan video tutorial dengan Camtasia. Output berupa nilai rata-rata kelas dari hasil post test. Berdasarkan data nilai ulangan harian (post test) siklus I, jumlah siswa yang tuntas adalah 25 siswa atau 71,43 \% . Jumlah siswa yang tidak tuntas adalah 10 siswa atau 28,57 \%. Tabel 4.4 menampilkan ketuntasan hasil belajar siswa pada siklus I. ranah psikomotorik disajikan oleh diagram pada Gambar 4 berikut ini:

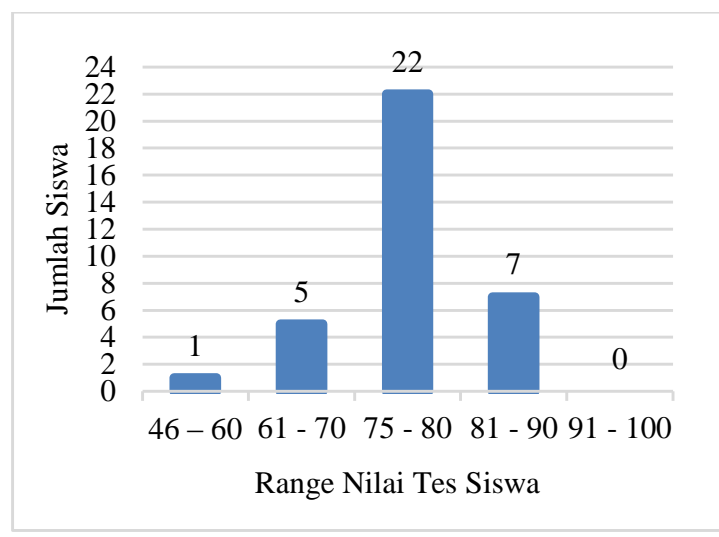

Gambar 4 Hasil Belajar Ranah Psikomotorik setelah Penerapan Video Tutorial dengan Camtasia Siklus I

Berdasarkan Gambar 4 untuk ketuntasan hasil belajar ranah psikomotorik siklus I terdapat 6 siswa yang tidak tuntas dan 28 siswa lainnya tuntas. Nilai yang paling banyak didapat siswa adalah pada range 75-80 dan sedangkan nilai terendah yaitu 57,14 didapat oleh 1 siswa.

3. Siklus II

Data siklus II dilaksanakan pada hari Selasa, 2 Mei 2017. Kehadiran siswa sebanyak 35 siswa. Berikut minat belajar siswa kelas $\mathrm{X}$ TGB B pada siklus II: 


\begin{tabular}{lll}
\hline No. & Aspek yang Diukur & Persentase \\
\hline 1 & Sikap & $74,29 \%$ \\
2 & Kemauan & $79,29 \%$ \\
3 & Ketertarikan & $81,43 \%$ \\
4 & Dorongan & $80,00 \%$ \\
5 & Ketekunan & $78,57 \%$ \\
6 & Perhatian & $79,29 \%$ \\
\hline Rata-rata Persentase & $78,81 \%$ \\
\hline
\end{tabular}

\begin{tabular}{ll}
\hline Target Ketercapaian & $75 \%$ \\
\hline Kategori Ketercapaian & Tercapai \\
\hline
\end{tabular}

\section{Berdasarkan tabel tersebut}

bahwa persentase minat belajar siswa masih belum memenuhi standar 75\%, aspek tertinggi ketertarikan karena siswa merasa tertarik dalam belajar dengan penerapan video tutorial Camtasia dan aspek terendah adalah sikap karena dalam pembelajaran siswa merasa video tutorial terlalu cepat dan membuat mereka tertinggal dalam hal mengerjakan maka ada siswa yang membuka program lain saat pembelajaran berlangsung.

Data hasil belajar siswa ranah kognitif disajikan oleh diagram pada Gambar 5 berikut ini:

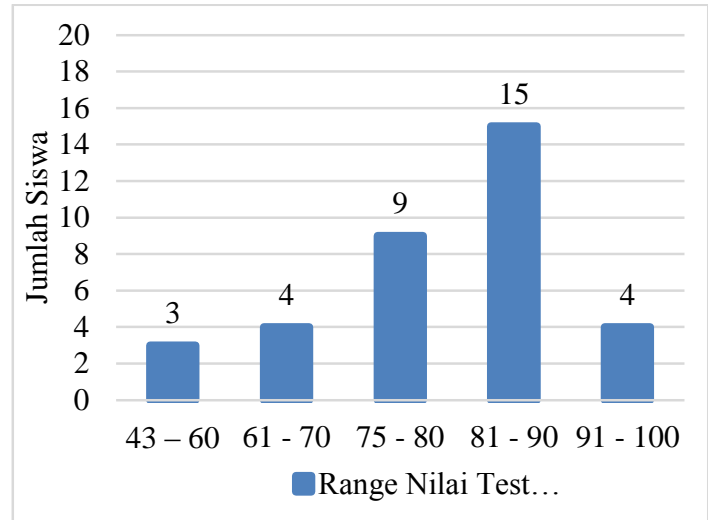

Gambar 5 Hasil Belajar Ranah Kognitif setelah Penerapan Video Tutorial dengan Camtasia Siklus II

Berdasarkan Tabel 4.8 nilai perolehan ranah kognitif siklus II > 75 , bertambah dibandingkan nilai siklus I. Jumlahnya menjadi 28, sedangkan jumlah siswa yang memperoleh nilai $<75$ sebanyak 7 siswa.

Keberhasilan hasil belajar ranah kognitif dalam penelitian ini dilihat dari aspek ketuntasan hasil belajar secara klasikal dan nilai rata-rata kelas. Berdasarkan data nilai ulangan harian (post test) siklus II, jumlah siswa yang tuntas adalah 28 siswa atau 80,00 $\%$. Jumlah siswa yang tidak tuntas adalah 7 siswa atau 20,00\%. 
Data hasil belajar siswa ranah psikomotorik disajikan oleh diagram pada Gambar 6 berikut ini:

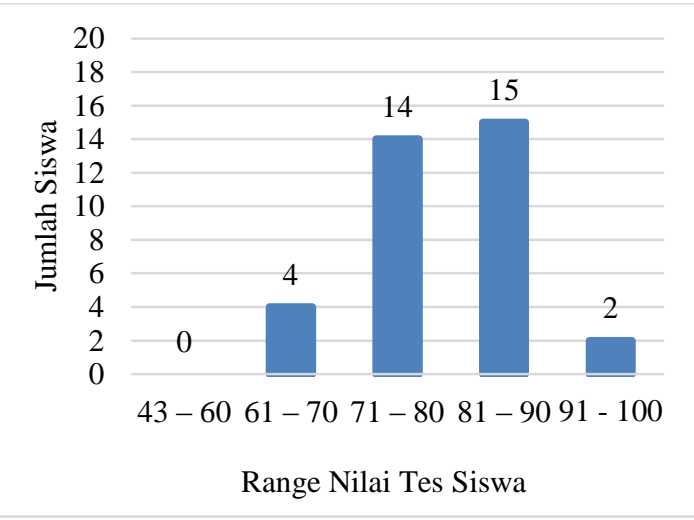

Gambar 6 Hasil Belajar Ranah Psikomotorik setelah Penerapan Video Tutorial dengan

Camtasia Siklus II

Berdasarkan Gambar 6 terdapat 4 siswa yang tidak tuntas atau 11,43 \% dari jumlah keseluruhan siswa sebanyak 35 siswa. Kurva pada Gambar 4.30 menunjukkan bahwa nilai yang paling banyak didapat siswa adalah pada range 81-90 dan hanya 2 siswa yang mendapatkan nilai paling rendah sebesar 60,71 . Alasan tidak adanya nilai 100 yang didapat siswa dikarenakan banyak siswa yang enggan untuk menyemprunakan hasil kerjanya.

\section{Pembahasan}

Pembelajaran menggambar dengan perangkat lunak dengan penggunaan video tutotial telah diterapkan pada pembelajaran di kelas X TGB B SMK Negeri 4 Sukoharjo dengan tujuan untuk meningkatkan minat dan hasil belajar siswa. Dalam pelaksanaannya, penelitian ini dilakukan dalam dua siklus. Siklus I terdiri dari 1 kali pertemuan. Siklus II terdiri dari 2 kali pertemuan. Pada siklus I dan II, alokasi waktu pada setiap pertemuan adalah $4 \times 45$ menit. Selama kegiatan pembelajaran berlangsung, dilakukan penilaian minat belajar siswa oleh 1 observer.

$$
\text { Permasalahan diawal }
$$
pembelajaran yang terlihat dari prasiklus sudah bisa diatasi pada siklus I, contohnya seperti kurangnya ketertarikan siswa dalam mengikuti pembelajaran dan kurangnya kemauan siswa untuk menyelasikan tugas mata pelajaran menggambar dengan perangkat lunak siswa harus diberi perintah terlebih dahulu. 
Berdasarkan tabel dan diagram yang disajikan pada perbandingan hasil tindakan antarsiklus, dapat diperoleh informasi bahwa penggunaan video tutorial berbasis Camtasia menggambar dengan perangkat lunak mampu meningkatkan minat siswa, yang meliputi sikap, kemauan, ketertarikan, dorongan, ketekunan dan perhatian. Persentase minat siswa mengalami peningkatan sesuai dengan tabel 4.12. Persentase minat siswa pada prasiklus sebesar 68,33 \%. Persentase minat siswa pada siklus I sebesar 72,14 \% Permasalahan yang terjadu pada siklus I adalah durasi waktu dan penerapan Video tutorial yang dirasa terlalu cepat, sudah bias diatasi pada siklus II. Persentase minat siswa pada siklus II sebesar 78,81 \%, Persentase minat siswa sudah mampu memenuhi indikator kinerja penelitian.

Hasil belajar siswa dilihat dari ketuntasan belajar siswa ranah kognitif juga mengalami peningkatan setelah penggunaan video tutorial menggambar denah rumah sederhana satu lantai dan tampak. Persentase ketuntasan belajar siswa sebelum tindakan adalah 45,71 \%. Permasalahan diawal pembelajaran yang terlihat dari prasiklus sudah bisa diatasi pada siklus I, nilai pada prasiklus nilai rata rata siswa 70,54 dan 3 siswa mendapat nilai 55. Pada siklus I persentase ketuntasan belajar siswa adalah 71,43 \% Permasalahan yang terlihat dari siklus I sudah bisa diatasi pada siklus II, nilai pada siklus I nilai rata rata siswa 71,77 . Pada siklus II persentase ketuntasan belajar siswa adalah 80,00\%. Persentase ketuntasan belajar siswa telah mencapai indikator kinerja penelitian.

Selain ketuntasan belajar ranah kognitif, nilai rata-rata kelas juga mengalami peningkatan setelah diberikan tindakan. Nilai rata-rata kelas sebelum diberikan tindakan adalah 70,54. Nilai ratarata kelas pada siklus I adalah 71,77. Nilai rata-rata kelas pada siklus II adalah 79,29. Nilai ratarata kelas telah memenuhi indikator kinerja penelitian. 
Hasil belajar siswa dilihat dari ketuntasan belajar siswa ranah psikomotorik juga mengalami peningkatan setelah penggunaan video tutorial dengan Camtasia menggambar denah rumah sederhana satu lantai dan tampak. Persentase ketuntasan belajar siswa sebelum tindakan adalah $65,71 \%$ Permasalahan diawal pembelajaran yang terlihat dari prasiklus sudah bisa diatasi pada siklus I, nilai pada prasiklus nilai rata rata siswa 72,83 dan 4 siswa mendapat nilai 60. Pada siklus I persentase ketuntasan belajar siswa adalah $74,76 \quad \%$ Permasalahan diawal pembelajaran yang terlihat dari prasiklus sudah bisa diatasi pada siklus I, nilai pada siklus I nilai rata rata siswa 74,90. Pada siklus II persentase ketuntasan belajar siswa adalah $88,57 \quad \%$ Permasalahan diawal pembelajaran yang terlihat dari siklus I sudah bisa diatasi pada siklus II, nilai pada prasiklus nilai rata rata siswa 79,69. Persentase ketuntasan belajar siswa telah mencapai indikator penelitian.
Selain ketuntasan belajar ranah psikomotorik, nilai rata-rata kelas juga mengalami peningkatan setelah diberikan tindakan. Nilai rata-rata kelas sebelum diberikan tindakan adalah 72,82. Nilai ratarata kelas pada siklus I adalah 74,90. Nilai rata-rata kelas pada siklus II adalah 79,69. Nilai ratarata kelas telah memenuhi indikator kinerja penelitian.

\section{SIMPULAN DAN SARAN}

\section{Simpulan}

Berdasarkan kajian teori dan didukung adanya hasil analisis yang mengacu pada perumusan masalah yang telah diuraikan pada bab sebelumnya, dapat disimpulkan sebagai berikut:

Pembelajaran menggambar dengan perangkat lunak menggunakan media video tutorial dengan Camtasia dapat meningkatkan minat belajar siswa kelas X TGB B SMK Negeri 4 Sukoharjo tahun ajaran 2016/2017. Persentase minat siswa pada prasiklus atau sebelum diterapkannya media video turorial dengan Camtasia didapat sebesar 
$68,33 \%$ siswa yang tuntas hal ini karena banyak siswa yang tidak paham, dan tidak tertarik pada mata pelajaran menggambar dengan perangkat lunak. Setelah diberikan tindakan atau menerapan media video tutorial dengan Camtasia pada siklus I minat belajar siswa adalah 72,14\% dan meningkat pada siklus II sebesar $78,81 \%$ siswa yang tuntas hal ini oleh peneliti disimpulkan penggunaan video tutorial dengan Camtasia membuat siswa menjadi terarik dan terdorong oleh adanya media baru yang menarik bagi siswa dan siswa menjadi lebih berminat saat pembelajaran terbimbing oleh guru.

Pembelajaran menggambar dengan perangkat lunak menggunakan media video tutorial dengan Camtasia dapat meningkatkan hasil belajar siswa kelas X TGB B SMK Negeri 4 Sukoharjo tahun ajaran 2016/2017. Ketuntasan hasil belajar siswa ranah kognitif mengalami peningkatan setelah diberikan tindakan. Persentase ketuntasan belajar siswa sebelum diberikan tindakan adalah 45,71\%. Setelah diberikan tindakan, pada siklus I persentase ketuntasan belajar siswa adalah $71,43 \%$ dan meningkat pada siklus II sebesar $80,00 \%$. Ketuntasan hasil belajar siswa ranah psikomotorik mengalami peningkatan setelah diberikan tindakan. Persentase ketuntasan belajar siswa sebelum diberikan tindakan adalah $65,71 \%$. Setelah diberikan tindakan, pada siklus I persentase ketuntasan belajar siswa adalah $74,76 \%$ dan meningkat pada siklus II sebesar 88,57\%.

\section{Saran}

Berdasarkan kesimpulan dan implikasi dalam penelitian ini, maka penulis mengajukan saransaran sebagai berikut:

1. Hendaknya siswa dapat memberikan sikap yang baik terhadap guru agar materi pembelajaran dapat berjalan dengan baik dan cepat dipahami.

2. Hendaknya guru dapat menyajikan materi menggaambar dengan perangkat lunak dengan video tutorial dengan baik sehingga 
dapat meningkatkan minat dan hasil belajar siswa.

3. Hendaknya peneliti lain yang ingin melakukan penelitian sejenis terlebih dahulu menganalisis kembali perangkat pembelajaran yang telah dibuat untuk disesuaikan penggunaannya terutama dalam hal fasilitas sarana prasarana dan karakteristik siswa yang ada pada sekolah penelitian tersebut.

\section{DAFTAR PUSTAKA}

Aripin. (2009). Step by Step Membuat Video Tutorial Menggunakan Camtasia Studio. Jakarta: Oase Media.

Sudijono, A. (2005). Pengantar Evaluasi Pendidikan. Jakarta: PT Raja Grafindo Persada.

Sri Muryanti. (2014). Penerapan Cooperatif Learning Tipe Think Pair Share Bermedia Tradisi Meron untuk Meningkatkan Minat dan
Hasil Belajar Siswa Terhadap Budaya Lokal (PTK di SMAN 1 Jakenan Pati). Tesis Tidak Dipublikasikan, Universitas Sebelas Maret, Surakarta

Suheri, Agus. (2006). Animasi Multimedia Pembelajaran. Jakarta: Elec Media Komputindo.

Susilana, R. \& Riyana, C. (2009). Media Pembelajaran Hakikat, Pengembangan, Pemanfaatan, dan Penilaian. Jakarta: CV Wacana Prima.

Sutopo, H.B. (2006). Metodologi Penelitian Kualitatif (dasar teori dan terapannya dalam penelitian). Surakarta: Universitas Sebelas Maret. 
